\title{
IT Usage for Enhancing Trade Show Performance: Evidence from the Aviation Services
}

\author{
Jaywant Singh ${ }^{1}$, Paurav Shukla, Stavros P. Kalafatis
}

\begin{abstract}
:
Purpose

While trade shows still remain an important CRM tool, recent advancements in information technology have raised concerns about the future of trade shows. This study examines the antecedents and consequences of information technology (IT) integration into trade shows.

Design/methodology/approach

The study employs a questionnaire-based survey with senior and middle managers in the aviation services, resulting in 135 valid responses. The data were analyzed using partial least squares structural equation modelling (PLS-SEM).

\section{Findings}

The findings demonstrate differential but significant impact of perceptions towards website design and firm motivations towards the integration IT in the three stages of trade shows marketing. The results also demonstrate significant impact of IT usage on the perceptions towards the accomplishment of trade show objectives. Further, the results vary according to the levels of experience of the professionals.
\end{abstract}

\section{Research Limitations}

This study did not account for the differences in perceptions towards IT implementation across personnel from different departments, such as IT, finance and operations management. In addition, it did not examine situational factors and individual characteristics as additional antecedents of IT usage in trade shows, including pricing, ROI, convenience and the social media.

\section{Practical Implications}

Exhibitors are advised to integrate IT in supporting pre-trade show activities to approach potential customers. Exhibitors should integrate electronic interactions and personal communications during the show to reduce the amount of unanswered customer queries, focusing on timeliness and accuracy of information content, ease of navigation, and graphic attractiveness of corporate websites, as effective CRM tools.

\section{Originality/value}

This paper offers insights into hitherto unknown aspects of trade show performance.

The results have managerial implications for adopting IT as a CRM tool for effective trade show management.

Keywords: trade shows, information technology, structural equation modeling, technology adoption

\footnotetext{
${ }^{1}$ Corresponding Author's Email: j.singh@kingston.ac.uk
} 


\section{Introduction}

Exhibitions and trade shows are central to business-to-business (b2b) marketing mix (Smith, Gopalakrishna, \& Smith, 2004). Trade shows are vital for initializing and developing international business relationships, monitoring international competition and enabling market entry for companies from various sectors (Geigenmuller, 2010) and thus act as an important Customer Relationship Management (CRM) tool. The trade shows industry has shown consistent growth during 2009-2012 in Europe and in the USA (CEIR, 2013). Czinkota and Ronkainen (2015) suggest that trade shows generate an annual yield of more than $\$ 100$ billion in revenue, with more than 24,500 trade shows held worldwide. Moreover, the authors suggest that trade shows are extremely cost-effective in terms of lead generation, as the average cost of making the first face-to-face contact with a potential customer through an exhibition lead is $\$ 96$, as compared to $\$ 1,039$ without. Despite the above growth, both industry experts (CEIR, 2013; UFI, 2013) and researchers (e.g., Kirchgeorg, Jung, \& Klante, 2010; Lilien, Oliva, \& Weirsema, 2013; Tafesse \& Korneliussen, 2013) point out significant challenges currently faced by this industry. One major challenge is the advancements in information and digital technology, and its integration with the current organizational CRM activities represents both a threat and an opportunity for the trade show industry (Ling-yee, 2010).

Information technology (IT) poses a threat as customers in b2b markets increasingly rely on information from digital media channels whilst overlooking the value of trade shows and exhibitions. This process is aided by the significant investments made by companies in digital software (ITE, 2013). In addition, the concept of online or 'virtual exhibitions' represents a cost-effective alternative to physical product demonstration, crossing geographical barriers and time zones (Sharma, 2002; Geigenmuller, 2010). The above shift in perceptions has led experts to raise concerns about the future of trade shows (EDPA, 2013; 
Lilien et al., 2013). However, IT also offers opportunities for show organizers, exhibitors and visitors. Through the use of digital content, trade show organizers can enhance several CRM activities such as, attract new exhibitors and visitors, promote the show in media and provide networking opportunities to industry professionals, beyond geographical and time constraints (Ducate, 2011). By providing information about products and services on the web, exhibitors communicate with potential buyers and attract visitors to the booth before the trade show starts. By doing so, attendees use web content to familiarize with products and services on display and to strategically plan their visits and networking activities (Lingyee, 2010). Such information-led convergence of activities (Shukla, 2010) between web content and trade shows can enable connectivity, competence and collaborations between b2b partner organizations.

Despite the above environmental changes, research examining trade shows remain sparse. Prior research investigates exhibitor and visitor motivation, criteria for the selection of trade shows (e.g., Smith et al., 2004; Gopalakrishna, Roster, \& Sridhar, 2010), and trade show performance evaluation (e.g., Dekimpe et al., 1997; Hansen, 2004; Gottlieb, Brown, \& Ferrier, 2014). None of the above studies, however, take into account the convergence of IT in supporting trade show effectiveness as a CRM tool. The integration of IT and its impact on the functioning of b2b companies has been widely reported (e.g., Morgan and Inks, 2001; Pullig, Maxham, \& Hair, 2002; Avlonitis and Panagopoulos, 2005; Senecal, Pullins, \& Buehrer, 2007; Moen, Madsen, \& Aspelund, 2008). Although Geigenmuller (2010) examines the use of IT in virtual tradeshows as an alternative to face-to-face events, the potential integration of digital technology with physical trade shows remains an intriguing and under-investigated question. This question is important because whilst the centrality of IT for trade shows has been highlighted in the business press (e.g., Weimar, 2013; Perez, 2014), academic research is largely silent on this issue. This study, hence, addresses the 
above research gap by investigating the antecedents and outcomes of IT integration in the context of trade shows. Given the continuous presence and growth of physical trade shows in today's digital age, the findings of this study help managers in optimizing trade show performance. The findings also inform exhibitors and $\mathrm{b} 2 \mathrm{~b}$ professionals on effective usage of IT in trade shows and can contribute towards enhancing their CRM efforts in achieving trade show objectives.

\section{Background Literature and Hypotheses Development}

With the increasing competition in the marketplace, extant literature on CRM has emerged largely from the $b 2 b$ practitioner perspective as firms tried to find effective ways of managing and sustaining their customer base (Hart, Hogg and Banerjee 2002). This relationship management is critical in b2b setting as lose of a single customer can have a dire and direct impact on company's bottomline and in some cases existence itself (Adidam and Sindhav, 2005). CRM holds the values and strategies of relationship marketing with a particular emphasis on customer relationships turned into practical application (Gummesson, 2004). Researchers assert that IT is a key element of CRM and for b2b setting the use of data-warehousing and data mining offer innovative opportunities to engage and build mutually beneficial long-term relationships (Eggert and Fassot, 2001). Gummesson (2004) particularly stresses the need for synergy between the electronic and the human elements for building a successful CRM implementation program.

Trade shows involving IT integration offers managers an opportunity to build the synergies between the electronic and human elements. Trade show participation involves several stages, each with specific CRM objectives and measures of success. In this regard, Gopalakrishna \& Lilien (1995) describe the process of exhibiting as consisting of three stages of pre-show, at- show and after-show activities. With well-developed IT integration, organizations can achieve their trade show objectives in several ways. For example, at 
pre-show stage, the website can offer potential customers to locate and send information concerning their queries as well as existing customers can plan ahead with regards to booth attendance and personalized communications (Ling-yee, 2010). When the trade show is happening, the interactive website can help employees demonstrate the products and services of the organization as well as help capture queries and solve client problems (Prasad, Ramamurthy, \& Naidu, 2001). A well-integrated website can also help achieve trade show objectives through post trade show promotion, client feedback and personalized communication with existing and potential clients (Ling-yee, 2010). The above post trade show activities are key towards creating an effective CRM strategy. Thus, as suggested in the b2b literature (Hart et al., 2004; Keramati, Mehrabi, \& Mojir, 2010), at each activity level CRM and IT integration in trade shows can enhance the overall perceived quality, efficiency of communication between interested parties, and help organizations achieve sales promotion objectives.

Pre-show activities include advertising, public relations, and promotion in advance of the trade show. These activities preclude and precede technical aspects of the show buildup, such as the booth construction and exhibits transportation to the venue (Kerin and Cron, 1987). General purpose of all pre-show activities is to attract current and potential customers to the fair, thus increasing the booth traffic (Geigenmuller, 2010). Since the overwhelming majority (79\%) of attendees of business-to-business trade shows plan their visit in advance and already know what booths to visit at the show (CEIR, 2013), pre-show activities are considered exhibitors' most significant marketing instrument in approaching potential customers (Lee and Kim, 2008). Previous research has identified a number of pre-show marketing activities, such as, quantifying show objectives (Kerin and Cron, 1987), preshow promotion (Dekimpe et al., 1997) and booth staff training (Ling-yee, 2007), as vital for the trade show performance of the company. 
In the context of pre and at trade show activities, Ling-yee (2010), Søilen (2013), and Tafesse and Korneliussen (2013) emphasize the relevance of internet technology design, such as information content, graphic attractiveness and navigation structure. For example, Montoya-Weiss et al (2003) show the positive impact of online channel use on overall satisfaction in the b2b context. Ellis-Chadwick and Doherty (2012) suggest that elements of content and attractiveness, such as usage of illustrations, and personalization, are important factors in overall CRM campaign success.

Prior studies report website design perceptions in relation to its information content timeliness and accuracy, ease of navigation, structure and layout attractiveness positively affects its usage as marketing channel (Montoya-Weiss et al., 2003; EllisChadwick and Doherty, 2012). Bart et al. (2005) suggest that people may perceive reduction of mistrust when visiting websites that provide good features and layout, as well as highquality content. Additionally, high quality design perceptions associated with a website can significantly affect trust, which is an influential driver for b2b transactions (Shukla, 2014). With regards to the adoption of website tools during trade shows, it is expected that if exhibitors display up-to-date and reliable information regarding participation on company website at pre-show stage, it will have a significantly higher usage at pre-trade show stage. It is, therefore, hypothesized that:

$\mathrm{H}_{1 \mathrm{a}}$ : The website design perceptions have a positive effect on the usage of IT for preshow promotion.

Similar to the pre-show activities, at-show activities have an important CRM purpose to attract potential customers to company booth (Lee and Kim, 2008) and to sell exhibitor products and services during the show (Ling-yee, 2010). The at-show marketing activities consist of determining booth size (Dekimpe et al., 1997) and booth location (Lee and Kim, 2008), on-site promotion (Lee and Kim, 2008) and on-site selling (Ling-yee, 
2010), along with booth staff density (Dekimpe et al., 1997). The at-show promotion provides important sources of information and evaluation of alternatives at the stage of purchase planning (Godar and O'Connor, 2001). However, the short duration of the atshow activities, restricted to mostly two or three days, means that converting contacts with potential customers at the show into sales leads becomes challenging and complex (Gopalakrishna and Lilien, 1995). The usage of website is not limited to external audiences in today's environment. With the rise in intranets, the usage of corporate website by the sales personnel as information source also depends on the website quality, especially if the website is easy to navigate and designed with user experience in mind. If the employees perceive the website design to be of high quality they will further promote the company to existing and potential clients at the trade show, thus leading to the following hypothesis:

$\mathrm{H}_{1 \mathrm{~b}}$ : The perceived design of company website has a positive effect on usage of IT for at-show promotion.

The literature generally refers to the post-show marketing activities as "post-show followup", and emphasizes the importance of follow-up for trade show performance effectiveness (e.g., Tanner, 2002; Ling-yee, 2007; Geigenmuller, 2010). The key objective of post-show follow-up is to ensure contacts with potential customers from the show, and to intensify interactions with existing clients (Geigenmuller, 2010), thus extending the event impact over a longer period of time (Lee and Kim, 2008). Researchers propose that aftershow follow-up should be used as controlling and measuring tool for specific trade show objectives (Lee and Kim, 2008). In this regard, studies on CRM-performance link suggest that effective IT integration leads to better lead management for the firm's CRM activities (Senecal et al., 2007; Keramati et al., 2010). Literature in both b2b and b2c domains suggest that the quality of the website design influences engagement and experience of the users (e.g., Chakravarti, Lala, \& Warren, 2002; Shukla, 2014). Industry reports suggest that user 
engagement and experience is influenced by temporal factors (Nielsen, 2011). Hence, an important success factor for after-show follow-up is the time taken by the company to respond to customer queries and personalized communications (Ling-yee, 2010). Better the perceived website design, easier it will be for the customers to use the website post trade show period to retrieve relevant information. Moreover, a favorably evaluated website design will facilitate company personnel to refer to and respond to customer queries. Thus, it is hypothesized that:

$\mathrm{H}_{1 \mathrm{c}}$ : The perceived design of company website has a positive effect on the usage of IT for after-show follow-up.

Previous b2b studies also show that a company's motivation and usage of IT depends on both organizational environment (Grewal, Comer, \& Mehta, 2001) and company's attempts to raise long-term economic efficiency (Wu, Mahajan, \& Balasubramanian, 2003). Grewal et al. (2001) in their conceptual research on electronic commerce proposed that organizational motivation in using new technology aims to enhance efficiency and achieve legitimacy. The efficiency motives are based on economic expectations and are consistent with basic reasons beyond the usage of internet technology in marketing, such as customer engagement and costs reduction (Grewal et al., 2001; Sharma, 2002). The employees are motivated to use IT in order to reduce cost, increase efficiencies, and create image that suggests a technologically advanced company (Grewal et al., 2001). On the other hand, legitimacy motives rely on institutional theory and are associated with company willingness to act according to existing business norms, competitors' behavior or societal expectations (Grewal et al., 2001). Employees seek to use IT in order to enhance marketplace reputation as well as respond to the competitors. Grewal et al.’s (2001) classification of motivational factors has been generalized in different 
environment, such as the e-business and trade shows (e.g., Wu et al., 2003; Ling-yee, 2010). Therefore, firm- related motivational factors are considered to have an impact on IT implementation in b2b firms' CRM activities.

Additionally, internet technologies can offer companies another avenue to legitimize their offerings. The trade shows are platforms for bringing together all industry players and influencers, therefore, it is expected that exhibitors will specifically aim to demonstrate a positive company image at trade shows, as well as the ability to successfully cope with required adoption of internet technologies (UFI, 2013). Since participation at trade shows often requires financial resources (Blythe, 2002), exhibitors may employ IT aimed at maximizing the return of marketing investments, including website usage. Therefore, it is posited that:

$\mathrm{H}_{2}$ : Emphasis on enhancing efficiency and legitimacy in firm-related motives will have a positive effect on usage of IT for (a) pre-show promotion (b) at-show promotion, and (c) after-show follow up.

A major aim of any CRM activity is to achieve desired firm objectives (Adidam and Sindhav 2005). In case of trade shows, firms may have several objectives including, maintaining customer contacts, getting new customer contacts, promoting existing product range and increasing the overall sales order. To achieve such objectives, sales managers in the b2b sector employ a wide variety of IT-based solutions using the internet as platform for commerce and co-ordinations. Several academic studies have investigated the impact of IT usage on business relationships and performance (e.g., Ryssel, Ritter, \& Gemunden, 2004; Avlonitis and Panagopoulos, 2005; Tong, Johnson, Umesh, \& Lee, 2008; Brady, Fellenz, \& Brookes, 2008), and the critical role of IT adoption for sales performance in $b 2 b$ firms has also been highlighted by recent studies (e.g., Homburg, Wieseke, \& Kuehnl, 2009; Hunter 
and Panagopoulos, 2015). IT integration can enhance the efficacy of pre and post sales activities (Tong et al., 2008). The integration of IT can potentially lead to the above benefits in trade shows as well. In this regard, Ling-yee (2010) suggests that the use of IT can enhance the employee and customer experience significantly throughout the trade show cycle. Hence, in order to fulfil sales objectives, trade show activities aimed at on-site sales promotion and sales maximization are enhanced when exhibitors exploit the usage of IT at pre-show promotion, promote sales at show, and use proper follow-up activities. It is, therefore, hypothesized that:

$\mathrm{H}_{3}$ : Usage of IT for (a) pre-show promotion (b) at-show promotion and (c) after-show follow-up has a positive effect on achievement of sales promotion objectives set for a trade show.

The moderating role of levels of experience (experts versus novices)

Prior research suggests that experiences of the individuals have an impact on organizational learning (Bedeian, 1986; Dixon, 1992; Feldman, 1986; Simon, 1991) with regards to CRM practices (Hart et al., 2004). In the context of b2b, new technologies continue to increase the efficiency and effectiveness of salespeople navigating through the sales process (Hunter and Panagopoulos, 2015). When initiating customer contact, IT can aid salespeople by giving them quicker access to better information and enables the salesperson to locate a larger prospect base in a shorter period of time (Keillor, Bashaw and Pettijohn, 1997). In addition to IT, the employee's level of experience can accord them the leverage to implement IT-enabled CRM activities effectively. In other words, experience with IT usage accords expertise, and employees with longer experience (the 'experts') will proffer greater IT usage activities than those with lower levels of experience (the 'novices'). Empirical evidence suggests differential behavior between experts and novices in a number 
of contexts, and ascribes this to individuals processing information corresponding to their level of experience (e.g., Nam and Sternthal, 2008; Stewart and Malaga, 2009; Kalafatis, Riley, \& Singh, 2014).

Therefore, in addition to the direct relationships $\left(\mathrm{H}_{1}-\mathrm{H}_{3}\right)$, it is expected that the level of experience of a company's employees will have an impact on IT usage at the three stages of the trade show promotion, as well as on the perceptions towards the overall achievement of trade show objectives. This follows from the reasoning that employees who have been with a company for longer period will differ in their perception of the company website and regarding the motives of the company for IT usage for trade shows promotion. The level of expertise and experience will also have an impact on the IT usage for pre-show promotion, at-show promotion, and after show promotion. In addition, the perceptions towards overall achievement of the trade show objectives will be contingent upon the level of employee experience. Hence, it is hypothesized that:

$\mathrm{H}_{4}$ : The varying levels of employee experience will have a differential impact on the IT usage at the three stages of trade show promotion, and overall achievement of the trade show objectives.

The above hypothesized relationships are summarized in the conceptual model in Figure 1. 


\section{Figure 1: Conceptual model}

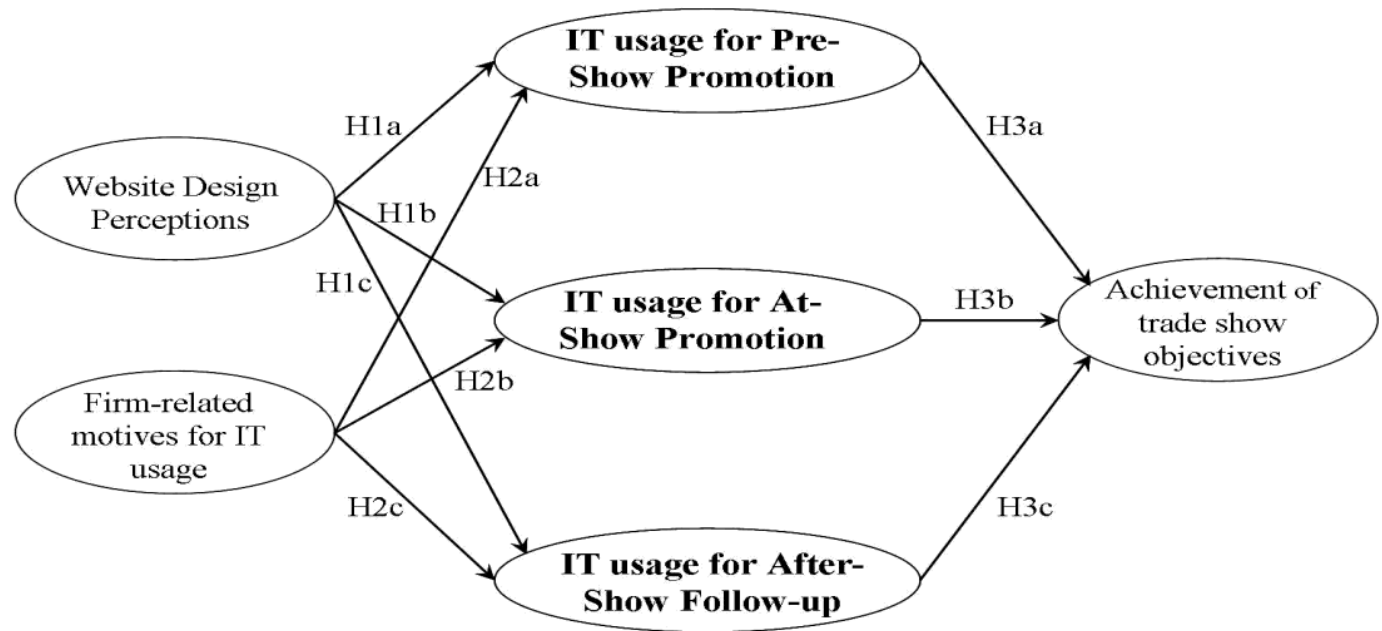

\section{Methodology}

In order to test the research hypotheses, this study adopts a survey-based quantitative approach. The context of this study is helicopter manufacturers and exhibitors within the aviation industry. Characterized by high growth, the global helicopter sector is currently valued at US\$22b (HIA, 2013). The sector is an oligopoly between five helicopter manufacturers, and the range of industry players includes governmental structures, training centres, insurance and leasing brokers, transportation and maintenance companies, helicopter operators and dealers. In order to market their products and services, these companies participate in a number of industrial trade shows each year (e.g., 50 helicopter shows are held annually in the USA alone).

A questionnaire was developed using established scales adopted and contextualized to measure the constructs in the model: a 10-items scale from Montaya-Weiss et al. (2003) to measure website design perceptions; 6 items scale from Grewal et al. (2001) and Ling-yee (2010) to measure 'firm-related motives'; 11 -items scale from Prasad et al. (2001) and Lingyee (2010) to measure 'IT usage activities'; and a 4-items scale developed by Hansen (2004) to measure achievement of trade show objectives (see all measures in Appendix table). The 
questionnaire was pre-tested with a small group of industry experts and academics in order to check for any inconsistencies and readability. The final questionnaire was uploaded on the online survery software Qualtrics, and was emailed to the potential respondents based in the helicopter industry throughout Europe. The sample included professionals (with a filter question about minimum 2 years of industry experience) from the helicopter industry, who participated in four main industry fairs in the previous two years. The respondents were asked to first browse the website of their firm, and then answer questions about perceptions to their company's website. Altogether 135 valid responses were received from senior and middle managers from the five helicopter firms and their ancillaries, as well as professional organizers of aviation trade shows, based across European countries. A question asking the number of years the respondent has worked in industry was included at the end of the questionnaire in order to achieve sub-samples of experts (more than 5 years' experience) and novices (less than 5 years' experience). Out of the total of 135, 70 responses were from the novices, and remaining 65 from the experts, giving two groups of comparable sizes.

\section{Results}

Given the focus of this study on developing theory for antecedents and consequences of trade shows, Partial Least Squares Structural Equation Modeling (PLS-SEM) was employed as analytical method (Hair, Sarstedt, Ringle, \& Mena 2012). Additionally, PLSSEM was adopted due to its suitability in producing robust results with a small sample size (Reinartz, Haenlein, \& Henseler, 2009; Hair, Hult, Ringle, \& Sarstedt, 2014). The PLS model estimation provides empirical measures of the relationships between the indicators and the constructs (measurement model), as well as between the constructs (structural model).

The model was estimated using SmartPLS 2.0 software (Ringle, Wende and Will, 2005), with bootstrap resampling analysis of 5,000 sub-samples, following Hair et al. (2014). 
First, evaluation of the measurement model confirmed reliability and validity of the constructs. The loadings of the items on their factors were greater than 0.70 and statistically significant. Composite reliability values were greater than 0.70 and the average variance extracted (AVE) estimates were greater than 0.50, thus indicating internal consistency.

Discriminant validity was confirmed through comparisons between the square correlation of a construct's AVE with its bivariate correlations with the remaining constructs (information not included here for brevity) (Fornell and Larcker's criterion, 1981). The above results are shown in Table 1. Further, discriminant validity is confirmed if the square root of a construct's AVE exceeds it bivariate correlations with other constructs in the model (Hair et al., 2014). The constructs met this criterion, as shown in Table 2.

Table 1: Testing Reliability and Validity

\begin{tabular}{|lccc|}
\hline Construct & $\begin{array}{c}\text { Cronbach's } \\
\text { Alpha }\end{array}$ & $\begin{array}{c}\text { Composite } \\
\text { Reliability } \\
(\mathrm{CR})\end{array}$ & $\begin{array}{c}\text { Average } \\
\text { Variance } \\
\text { Extracted (AVE) }\end{array}$ \\
\hline IT usage for at-show promotion & .852 & .910 & .771 \\
Firm-related motives for IT usage & .940 & .953 & .799 \\
IT usage for after-show follow-up & .752 & .843 & .577 \\
Website design perceptions & .850 & .880 & .428 \\
IT-usage for pre-show promotion & .749 & .843 & .576 \\
Achievement of trade show objectives & .830 & .888 & .666 \\
\hline
\end{tabular}

Table 2: Testing for Discriminant Validity

\begin{tabular}{|lrrrrr|}
\hline & 1 & 2 & 3 & 4 & 5 \\
\hline IT usage for at-show promotion & $\mathbf{. 8 8}$ & & & & \\
Firm-related motives for IT usage & .55 & $\mathbf{. 8 9}$ & & & \\
IT usage for after-show follow-up & .60 & .50 & $\mathbf{. 7 6}$ & & \\
IT-usage for pre-show promotion & .66 & .46 & .54 & $\mathbf{. 7 6}$ & \\
Achievement of trade show objectives & .76 & .49 & .59 & .64 & $\mathbf{. 8 2}$ \\
\hline
\end{tabular}

Notes:

a) Key: 1= IT usage for at-show promotion; $2=$ Firm-related motives for IT usage; $3=$ IT usage for aftershow follow-up; 4 = IT-usage for pre-show promotion; $5=$ Achievement of trade show objectives

b) Off diagonals are bivariate correlations, bold diagonals are square root of corresponding AVE.

The analysis of the structural model involved assessment of the $\mathrm{R}^{2}$ values of the dependent variables, the statistical significance of the hypothesized pathways of the model, 
and the Stone-Geisser $\left(\mathrm{Q}^{2}\right)$ index for predictive relevance of the overall model. The results presented in Table 3 provide evidence of considerable explanatory $\left(\mathrm{R}^{2}\right.$ ranging between .30 and .69) and predictive power $\left(\mathrm{Q}^{2}=\right.$ positive $)$ of the conceptual model. All hypothesized relationships are significant, with the exception of the functional relationships between the firm-related motives for IT usage and its impact on IT usage for pre-show promotion, the hypothesized pathways between IT usage for after show follow-up and achievement of trade show objectives. Hence, all research hypotheses are accepted, with the exception $\mathrm{H} 1_{\mathrm{a}}$ and $\mathrm{H} 3_{\mathrm{b}}$ which are not supported.

Table 3: Testing the structural model for full sample

\begin{tabular}{|c|c|c|c|}
\hline \multicolumn{3}{|l|}{ Functional Relationships } & $\begin{array}{l}\text { Standardized } \\
\text { path coefficients } \\
(t \text {-values })\end{array}$ \\
\hline \multicolumn{3}{|c|}{ Web design perceptions $\rightarrow$ IT usage for pre-show promotion $\left(\mathrm{H}_{1 \mathrm{a}}\right)$} & $.649(9.42)^{* * *}$ \\
\hline \multicolumn{3}{|c|}{ Web design perceptions $\rightarrow$ IT usage for at-show promotion $\left(\mathrm{H}_{1 \mathrm{~b})}\right.$} & $.232(2.83)^{* *}$ \\
\hline \multicolumn{3}{|c|}{ Web design perceptions $\rightarrow$ IT usage for after show follow-up $\left(\mathrm{H}_{1 \mathrm{c})}\right.$} & $.638(13.46)^{* * *}$ \\
\hline \multicolumn{3}{|c|}{ Firm-related motives for IT usage $\rightarrow$ IT usage for pre-show promotion $\left(\mathrm{H}_{2 \mathrm{a}}\right)$} & $.046(.47)$ \\
\hline \multicolumn{3}{|c|}{ Firm-related motives for IT usage $\rightarrow$ IT usage for at-show promotion $\left(\mathrm{H}_{2 b}\right)$} & $.375(3.94)^{* * *}$ \\
\hline \multicolumn{3}{|c|}{ Firm-related motives for IT usage $\rightarrow$ IT usage for after show follow-up $\left(\mathrm{H}_{2 c}\right)$} & $.255(4.86) * * *$ \\
\hline \multicolumn{3}{|c|}{ IT usage for pre-show promotion $\rightarrow$ Achievement of trade show objectives $\left(\mathrm{H}_{3 \mathrm{a}}\right)$} & $.258(4.48)^{* * *}$ \\
\hline \multicolumn{3}{|c|}{ IT usage for at-show promotion $\rightarrow$ Achievement of trade show objectives $\left(\mathrm{H}_{3 \mathrm{~b}}\right)$} & $.661(12.52)^{* * *}$ \\
\hline \multicolumn{3}{|c|}{ IT usage for after show follow-up $\rightarrow$ Achievement of trade show objectives $\left(\mathrm{H}_{3 \mathrm{~b}}\right)$} & $-.013(.215)$ \\
\hline & & $Q^{2}$ & \\
\hline IT usage for pre-show promotion & .46 & .32 & \\
\hline IT usage for at-show promotion & .30 & .42 & \\
\hline IT usage for after show follow-up & .66 & .18 & \\
\hline Achievement of trade show objectives & 69 & .21 & \\
\hline
\end{tabular}

Similar to the assessment of the measurement model for the full sample, reliability and validity tests were conducted for the two sub samples (experts $=65$, novices $=70$ ). The constructs displayed satisfactory levels of reliability. All cross loadings met the benchmark of 0.7 and were highly related to their respective constructs. All AVE values exceeded 0.5, confirming convergent validity. Similarly, square roots of constructs' AVE were greater than their correlation with other constructs in the model, thus confirming discriminant validity. Both models show considerable explanatory power, with $\mathrm{R}^{2}$ values ranging between .32 and 
.69 for the experts, and between .30 and .69 for the novices. Table 4 shows results from the structural model for the two samples, including standardized path coefficients, $t$-values, and $\mathrm{R}^{2}$ values.

Table 4: Testing the structural model for experts vs novices

\begin{tabular}{|lll|}
\hline & $\begin{array}{l}\text { Experts }(n=65) \\
\text { Stand. path } \\
\text { Functional Relationsients } \\
(t \text {-values })\end{array}$ & $\begin{array}{l}\text { Novices }(n=70) \\
\text { Stand. path } \\
\text { coefficients } \\
(t \text {-values })\end{array}$ \\
\hline Web design perceptions $\rightarrow$ IT usage for pre-show promotion $\left(\mathrm{H}_{1 \mathrm{a}}\right)$ & $.322(3.32)^{* * *} .649(6.92)^{* * *}$ \\
Web design perceptions $\rightarrow$ IT usage for at-show promotion $\left(\mathrm{H}_{1 \mathrm{~b}}\right)$ & $.276(3.20)^{* * *}$ & $.232(1.53)$ \\
Web design perceptions $\rightarrow$ IT usage for after show follow-up $\left(\mathrm{H}_{1 \mathrm{c}}\right)$ & $.262(1.69)^{*}$ & $.638(9.21)^{* * *}$ \\
Firm-related motives for IT usage $\rightarrow$ IT usage for pre-show promotion $\left(\mathrm{H}_{2 \mathrm{a}}\right)$ & $.537(5.22)^{* * *} .046(0.33)$ \\
Firm-related motives for IT usage $\rightarrow$ IT usage for at-show promotion $\left(\mathrm{H}_{2 \mathrm{~b}}\right)$ & $.642(7.69)^{* * *} .375(2.79)^{* *}$ \\
Firm-related motives for IT usage $\rightarrow$ IT usage for after show follow-up $\left(\mathrm{H}_{2 \mathrm{c}}\right)$ & $.373(2.26)^{* *}$ & $.255(3.27)^{* * *}$ \\
IT usage for pre-show promotion $\rightarrow$ Achievement of trade show objectives $\left(\mathrm{H}_{3 \mathrm{a}}\right)$ & $.156(0.83)$ & $.258(3.19)^{* * *}$ \\
IT usage for at-show promotion $\rightarrow$ Achievement of trade show objectives $\left(\mathrm{H}_{3 \mathrm{~b}}\right)$ & $.358(1.51)$ & $.661(8.98)^{* * *}$ \\
IT usage for after show follow-up $\rightarrow$ Achievement of trade show objectives $\left(\mathrm{H}_{3 \mathrm{~b}}\right)$ & $.272(2.16)^{* * *}$ & $-.013(.163)$ \\
$\mathbf{R}^{2}$ & & .59 \\
IT usage for pre-show promotion & .69 & .46 \\
IT usage for at-show promotion & .32 & .30 \\
IT usage for after show follow-up & .45 & .66 \\
Achievement of trade show objectives & .69
\end{tabular}

Note: $\quad * p<.05 ; * * p<.01 ; * * * p<.001$

In terms of the structural relationships, the two groups show differential results in some cases. For the antecedents, the impact of web design perceptions on IT usage for atshow promotion is significant for the experts, but non-significant for the novices. Similarly, the impact of firm-related motives for IT usage has a significant impact on IT usage for preshow promotion for the experts, but non-significant for the novices. For the consequences, the impact of IT usage for pre-show and at-show promotion on achievements of trade show objectives show a non-significant relationship for the experts, whereas the relationships are significant for the novices. 


\section{Discussion and Conclusions}

This study investigates the impact of IT-related factors on trade show activities. The study makes several important contributions to $\mathrm{b} 2 \mathrm{~b}$ and trade shows literature. The results confirm the role of website design perceptions as significant antecedent of IT usage in trade shows marketing. This is consistent with previous studies on the impact of internet-based marketing tools (e.g., Montoya-Weiss et al., 2003; Wu et al., 2003; Tafesse \& Korneliussen, 2013), showing that navigation structure, graphic style and information content are important determinants of on-line channel usage. Further, the study reveals that the influence of website design perceptions on trade show activities is particularly strong at the pre and after show promotion stages.

The results show that firm-related motivation for IT usage is an important antecedent of internet technology usage for the at-show and after show follow up stages of trade show marketing. The findings support the concept of institutional motivation in entering $b 2 b$ electronic markets (Grewal et al., 2001). At-show promotion plays an important role in attracting customers to company booth and advertising company's participation in the trade show. At-show promotion also contributes to generating sales leads and building the company image, widely established measures of trade show evaluation (Blythe, 2002). Given that the exhibitors usually try to maximize the return on resources spent on trade show participation, the perceptions towards IT usage affects marketing activities during at-show and after show stages. The findings show the central role played by firm's motivations and current practices towards the use of IT and its impact on trade show promotional activities.

Further, the results in this study demonstrate significant and positive effect of IT usage for pre-show and at-show promotion on the perceptions towards the exhibition's objectives being met, but not for the post show follow up. In this regard, Rosson and Seringhaus (1995) emphasized the role of personal interactions on after show sales and raised doubts 
about the possibility of IT implication at this stage. However, Geigenmuller (2010) shows integration of virtual technologies as key element of successful modern exhibition. In sum, this study provides empirical support for the importance of IT in trade show activities. The effective usage of IT during the trade show can reduce the number of unanswered customer queries and increase the amount of on-site sales, thus reducing concerns over after-show follow-up for trade show performance effectiveness.

The results for the experts and the novices show that there are differences accordingly to the level of industry experience amongst the respondents. For example, the effect of IT usage for at-show promotion on exhibition performance was found to be significant for the group of experts, but non-significant for the novices. This result can be explained in line with network theory (e.g., Evers and Knight, 2008) wherein with long-term involvement in the industry, a professional is usually able to develop large number of contacts. Thus in meeting professional goals, including achieving of trade show objectives, experts are more likely to rely on personal interactions inside their social professional network through communication via internet. Besides, a more experienced employee is expected to have deeper knowledge of company products and services and, accordingly, can refer to additional information sources, such as company web-site, during the sales negotiations. In addition, the experience gained in the specific industry (helicopter industry) can be complementary to the expertise in IT application.

Further, the novices do not show a significant impact of firm-related motives on IT usage for pre-show promotion. This result indicates the lower levels of involvement and knowledge about the firm's motives for IT usage and it may have a negative impact on preshow promotion. In addition, the perceptions of the experts about the pre and at-show IT usage having an impact on trade show achievements are non-significant. This result could be due to general skepticism about the pre and at-show objectives being met. This 
interpretation is consistent with the experts showing a significant impact of IT usage for after show follow-up on the achievement of trade show objectives. The experts, having gained industry-specific knowledge, are more goal-oriented, and hence the above results. On the other hand, the study empirically demonstrates that firm-related motivation do affect IT usage for pre-show promotion only among more experienced respondents. Despite their reliance on personal professional networks, the experts do realize the importance of IT usage in terms of increasing efficiency and achieving legitimacy of company business processes.

\section{Managerial Implications, Limitations and Further Research}

The findings of this research have several managerial implications. The trade show business continues to expand despite the rapid IT advancements. An important implication, therefore, relate to the integration of IT with CRM activities of the companies participating in the trade shows. The study found significant influence of IT usage on trade show performance, therefore, the exhibitors are advised to strongly integrate internet-based tools in supporting trade show activities and post-show CRM activities. This will help in achieving cost-effectiveness, and the exhibitors should employ website and e-mail marketing to approach potential customers at the stage of impersonal pre-show promotion. Pre-show relational activities will help in boosting booth traffic and chances of successful sales leads at the show.

A perusal of websites pertaining to major helicopter industry players shows largely static webpages and a lack of interactivity and IT integration. The content displayed on the websites does not indicate the use of latest technological advancements which can enhance the overall CRM efforts such as data mining and data warehousing. Since the findings of this study show that IT usage for pre-show promotion is affected by the quality of website design, therefore, exhibitors should pay attention on timeliness and accuracy of information 
content, ease of navigation and graphic attractiveness of corporate websites as effective marketing tools of trade show management.

Moreover, exhibitors are recommended to use electronic interactions and personal communications during the show to increase the synergies between human and electronic elements (Gummesson, 2004). This will enable booth personnel to manage customer support activities at the show, thus reducing follow-up time. To encourage booth personnel to use IT during the show, exhibitors can emphasize cost reduction, operational efficiency and enhancement of company image. Overall, the exhibitors stand to benefit adopting an overarching view towards the integration of IT tools into their trade shows for a long-term CRM strategy.

The study limitations provide avenues for further research. Further research could investigate differences in perceptions towards internet technologies implementation into trade show marketing across personnel from different departments, such as IT, finance and operations management. In addition, a future study could investigate the implementation of social media and other rapidly developing digital communication tools for trade show activities. Similarly, research could examine situational factors and individual characteristics as additional antecedents of IT usage in trade shows, including pricing, return on investments, convenience and Internet expertise. Lastly, future research can examine the effect of IT usage in trade shows on the achievement of non-sales exhibition objectives, such as information gathering, corporate image-building, relationship improvement, and employee motivation enhancement. 


\section{References}

Adidam, P. T. and Sindhav, B. (2005), "Customer Relationship Management: Critical Issues in Implementation", National Social Science Journal, Vol. 23 No. 2, pp. 1-8.

Avlonitis, G. J. and Panagopoulos, N. G. (2005), “Antecedents and consequences of CRM technology acceptance in the sales force," Industrial Marketing Management, Vol. 34 No. 4, pp. 355-368.

Bart, Y., Shankar, V., Sultan, F. and Urban, G. (2005), "Are the drivers and role of online trust the same for all web sites and consumers? A large-scale exploratory empirical study", Journal of Marketing, Vol. 69 No. 4, pp. 133-152.

Bedeian, A. G. (1986), "Contemporary challenges in the study of organizations," Journal of Management, Vol. 12, pp. 185-201.

Blythe, J. (2002), “Using trade fairs in key account management”, Industrial Marketing Management, Vol. 31 Issue 7, pp. 627-635.

Brady, M., Fellenz, M. and Brookes, R. (2008), "Researching the role of information and communications technology (ICT) in contemporary marketing practices," Journal of Business \& Industrial Marketing, Vol. 23 No. 2, pp. 108-114.

Center for Exhibition Industry Research (CEIR 2013), “An Analysis of the 2012 Exhibition Industry \& Outlook", available at: http://www/ceir.org (accessed 7 March 2014).

Chakravarti, G., Lala, V. and Warren, D. (2002), “An empirical investigation of antecedents of B2B websites' effectiveness," Journal of Interactive Marketing, Vol. 16 Iss. 4, pp. $51-72$.

Czinkota, M., and Ronkainnen, I. (2015), “An academic assessment of international trade shows," Marketing News, April, available at: http://michaelczinkota.com/wpcontent/uploads/2015/04/trade-shows-April-2015.pdf ) 
Dekimpe, M., Francois P., Gopalakrishna S., Lilien, G. and vanden Bulte, C. (1997), "Generalizing tradeshow effectiveness: a cross-national comparison", Journal of Marketing, Vol. 61 No. 4, pp. 55-64.

Dixon, N. M. (1992), “Organizational learning: A review of the literature with implications for HRD professionals," Human Resource Development Quarterly, Vol. 3, pp. 29- 49.

Ducate, D. (2011), "Exhibition Industry Outlook”, The Exhibit Designers and Producers Association, available at: http://www.edpa.com (accessed on 7 March 2014).

Eggert, A., and Fassot, G. (2001), Eds. eCRM: Electrontic Customer Relationship Management, Schäffer-Poeschel: Stuttgart.

EDPA (2013), “Exhibit Designers and Producers Association”, available at: http://www.edpa.com (accessed 7on March 2014).

Ellis-Chadwick, F. and Doherty, N. F. (2012), "Web advertising: The role of e-mail marketing", Journal of Business Research, Vol. 65 No. 6, pp. 843-848.

Evers, N. and Knight, J. (2008) "Role of international trade shows in small firm internationalization: a network perspective”, International Marketing Review, Vol. 25 No. 5, pp. 544-562.

Feldman, J. (1986), “On the difficulty of learning from experience,” In: H. P., Simms Jr., \& D. A. Gioia, et al. (Eds.), The thinking organization (pp. 263 - 292). San Francisco: Jossey-Bass Publishers.

Fornell, C. and Larcker, D. (1981), "Evaluating structural equation models with unobservable variable and measurement error", Journal of Marketing Research, Vol. 18 No. 1, pp. $39-50$.

Geigenmuller, A. (2010), “The role of virtual trade fairs in relationship value creation”, Journal of Business and Industrial Marketing, Vol. 25 No. 4, pp. 284-292.

Godar, S.H. and O'Connor, P.J. (2001) "Same Time Next Year-Buyer Trade Show 
Motives ," Industrial Marketing Management, Vol. 30 No. 1, pp.77-86.

Gopalakrishna, S. and Lilien, G. (1995), “A three-stage model of industrial trade show performance”, Marketing Science, Vol. 14 No. 1, pp. 22-42.

Gopalakrishna, S., Roster C. and Sridhar, S. (2010), “An exploratory study of attendee activities at a business trade show", Journal of Business \& Industrial Marketing, Vol. 25 No. 4, pp. 241-248.

Gottlieb, U., Brown, M. and Ferrier, L. (2014), “Consumer perceptions of trade show effectiveness: scale development and validation within a B2C context," European Journal of Marketing, Vol. 48 No. 1/2, pp. 89-107.

Grewal, R., Comer, J. and Mehta, R. (2001), “An Investigation into the Antecedents of Organizational Participation in Business-to-Business Electronic Markets," Journal of Marketing, Vol. 65 No. 3, pp. 17-33.

Gummesson, E. (2004), "Return on relationships (ROR): The value of relationship marketing and CRM in business-to-business contexts," Journal of Business \& Industrial Marketing, Vol. 19 No. 2, pp. 136-148.

Hair J.F., Sarstedt, M., Ringle, C.M. and Mena, J.A. (2012), "PLS-SEM: Indeed a Silver Bullet", Journal of Marketing Theory and Practice, Vol. 18 No. 2, pp. 139-151.

Hair, J., Hult, G., Ringle, C. and Sarstedt, M. (2014), A Primer on Partial Least Squares Structural Equation Modeling (PLS-SEM), Sage, Inc.

Hansen, K. (2004), “Measuring Performance at Trade Shows: Scale development and validation”, Journal of Business Research, Vol. 57 Issue 1, pp. 1-13.

HIA (2013), “Helicopter Market Newsletter”, Helicopter Association International (2013), available at: http://www.rotor.com/Publications/HelicopterMarketNewsletter.aspx (accessed 7 March 2014). 
Hart, S., Hogg, G. and Banerjee, M. (2002), “An Examination of Primary Stakeholders' Opinions in CRM: Convergence and Divergence?" Journal of Customer Behaviour, Vol. 1 No. 2, pp. 241-267.

Homburg, C., Wieseke, J. and Kuehnl, C. (2009), “Social influence on salespeople's adoption of sales technology: A multilevel analysis," Journal of the Academy of Marketing Science, Vol. 38 No. 2, pp. 159-168.

Hunter, G. K. and Panagopoulos, N. G. (2015), "Commitment to technological change, sales force intelligence norms, and salesperson key outcomes," Industrial Marketing Management, http://dx.doi.org/10.1016/j.indmarman.2015.03.023.

ITE Group (2013),”Chairman \& CEO’s statement”, available at: http://www.iteexhibitions.com/ceos.aspx (accessed 7 March 2014).

Kalafatis, S., Riley, D. and Singh, J. (2014), "Context Effects in the Evaluation of Businessto-Business Brand Alliances,” Industrial Marketing Management, Vol. 43 Iss. 2, pp. 322-334.

Keillor, B., Bashaw, E. and Pettijohn, C. (1997), "Salesforce automation issues prior to implementation: the relationship between attitudes toward technology, experience and productivity," Journal of Business \& Industrial Marketing, Vol. 12 No. 3/4, pp. 2019219.

Keramati, A., Mehrabi, H. and Mojir, N. (2010), “A process-oriented perspective on customer relationship management and organizational performance: An empirical investigation," Industrial Marketing Management, Vol. 39 Iss. 7, pp. 1170-1185.

Kerin, R. and Cron, W. (1987), “Assessing trade show functions and performance: an exploratory study", Journal of Marketing, 51 No. 3, pp. 87-94. 
Kirchgeorg, M., Jung, K. and Klante, O. (2010), "The future of trade shows: insights from a scenario analysis”, Journal of Business \& Industrial Marketing, Vol. 25 No. 4, pp. 301312.

Lee, C. H. and Kim, S. Y. ( 2008), "Differential effects of determinants of multi-dimensions of trade show performance: By three stages of pre-show, at-show and post-show activities," Industrial Marketing Management, Vol. 37 Iss. 7, pp. 784-796.

Lilien, G., Oliva R. and Wiersema, F. (2013), "The current state of B2B marketing and a look ahead", Industrial Marketing Management, Vol. 42 No. 4, pp. 470-488.

Ling-yee, Li (2007), "Marketing resources and performance of exhibitor firms in trade shows: a contingent resource perspective", Industrial Marketing Management, Vol. 36 No. 3, pp. 360-372.

Ling-yee, L. (2010), “Antecedents and effect of internet implementation for trade shows", Journal of Business \& Industrial Marketing, Vol. 25 No. 4, pp. 272-283.

Moen, O., Madsen, T.K. and Aspelund, A. (2008), "The importance of the internet in international business-to-business markets”, International Marketing Review, Vol. 25 No. 5, pp. 487-503.

Montoya-Weiss, M., Voss, G. and Grewal, D. (2003), "Determinants of online channel use and overall satisfaction with a relational, multichannel service provider", Journal of the Academy of Marketing Science, Vol. 31 No. 4, pp. 448-458.

Morgan, A. J. and Inks, S. A. (2001), "Technology and the sales force," Industrial Marketing Management, Vol. 30 No. 5, pp. 463- 472.

Nam, M. and Sternthal, B. (2008), "The effects of a different category context on target brand Evaluations," Journal of Consumer Research, Vol. 35 No. 4, pp. 668-679.

Perez, T. (2013), Awesome Trade Show, Carmine Media, available at: http://carminemedia.com/2014/03/11/four-tips-for-a-successful-trade-show-hint-usesocial-media/ (accessed on 7 November, 2014). 
Prasad, V., Ramamurthy, K. and Naidu, G. (2001), "The Influence of internet-marketing integration on marketing competencies and export performance", Journal of International Marketing, Vol. 9 No. 4, pp. 82-110.

Pullig, C., Maxham, III, J. G. and Hair, J. F., Jr. (2002), “Salesforce automation systems: An exploratory examination of organizational factors associated with effective implementation and salesforce productivity," Journal of Business Research, Vol. 55 No. 5, pp. 401- 415 .

Reinartz, W., Haenlein, M. and Henseler, J. (2009), “An empirical comparison of the efficacy of covariance-based and variance-based SEM," International Journal of Research in Marketing, Vol. 26 No. 4, pp. 332-344.

Ringle, C.,Wende, S., and Will, A. (2005), SmartPLS 2.0 (M3) Hamburg, available at: http://www.smartpls.de.

Rosson P.J. and Seringhaus, F. (1995), "Visitor and exhibitor interaction at industrial trade fairs", Journal of Business Research, Vol. 32 No. 1, pp. 81-90.

Ryssel, R., Ritter, T. and Gemunden, H.G. (2004), “The impact of information technology deployment on trust, commitment and value creation in business relationship", Journal of Business \& Industrial Marketing, Vol. 19 No. 3, pp. 197-207.

Senecal, S., Pullins, E. B. and Buehrer, R. E. (2007), “The extent of technology usage and salespeople: an exploratory investigation," Journal of Business \& Industrial Marketing, Vol. 22 No. 1, pp. 52-61.

Sharma, A. (2002), “Trends in Internet-based business-to-business marketing”, Industrial Marketing Management, Vol.31 No. 2, pp. 77-84.

Shukla, P. (2010), "Relationship Marketing and CRM", in Bidgoli, H. (ed), The Handbook of Technology Management, pp. $462-472$. 
Shukla, P. (2014), "The impact of organizational efforts on consumer concerns in an online context", Information \& Management, Vol. 51 No. 1, pp. 113-119.

Simon, H. A. (1991), “Bounded rationality and organizational learning,” Organization Science, Vol. 2, pp. 125-134.

Smith, T., Gopalakrishna, S.,p and Smith, P. (2004), “The complementary effect of trade shows on personal selling," International Journal of Research in Marketing, Vol. 21 Issue 1, pp. 61-76.

Søilen K. S. (2013) Exhibit Marketing and Trade Show Intelligence. Springer Berlin Heidelberg, Second Edition.

Stewart, K. J. and Malaga, R. A. (2009), “Contrast and assimilation effects on consumers' trust in Internet companies," International Journal of Electronic Commerce, Vol. 13 No. 3, pp. 71-93.

Tafesse, W. and Korneliussen, T. (2013), "Examining the effect of using multiple media tools on the marketing performance of organisations in a trade campaign environment", Journal of Marketing Communications, Vol. 19 No. 3, pp. 215.

Tanner, J. F. Jr. (1994), “Adaptive Selling at Trade Shows”, Journal of Personal Selling and Sales Management, Vol. 14 No. 2, pp.15-24.

The Global Association of the Exhibition Industry, UFI (2013), available at: http://www.ufi.org (accessed 7 March 2014).

Tong, P., Johnson, J.L., Umesh, N.N. and Lee, R.P. (2008), “A typology of interfirm relationships: the role of information technology and reciprocity", Journal of Business \& Industrial Marketing, Vol. 23 No. 3, pp. 178-92.

Weimar, M. (2014), Trade Show displays go digital for increased engagement, MarketingTech, available at: http://www.marketingtechnews.net/news/2013/jul/04/trade-show-displays-go-digitalincreased-engagement/ (accessed on $15^{\text {th }}$ November, 2014). 
Wu, F., Mahajan, V. and Balasubramanian, S. (2003), “An analysis of e-business adoption and its impact on business performance", Journal of the Academy of Marketing Science, Vol. 31 No. 4, pp. 425-447.

\section{Acknowledgement:}

The authors express their gratitude to Kate Noskina for helping with data collection. 
APPENDIX: Measures Table

\begin{tabular}{|c|c|}
\hline Constructs & Items \\
\hline 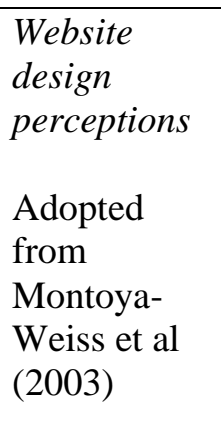 & $\begin{array}{l}\text { Information on my company's website is reliable } \\
\text { Information on my company's website enhances informed decisions } \\
\text { Information on my company's website is up-to-date } \\
\text { It is easy to move around my company's website using very few clicks } \\
\text { It is easy to find what I am looking for on my company's website. } \\
\text { It is easy to remember the name of my company's website } \\
\text { My company's website can create personalized service offerings to customers } \\
\text { My company's website's graphic design layout is attractive } \\
\text { My company's website's text and graphics can be downloaded quickly } \\
\text { My company's website provides interactive functions for customers }\end{array}$ \\
\hline $\begin{array}{l}\text { Firm-related } \\
\text { motives for } \\
\text { IT usage } \\
\text { Adopted } \\
\text { from Grewal } \\
\text { et al. (2001) }\end{array}$ & $\begin{array}{l}\text { At my company the staff are motivated to use IT in marketing activities because it is } \\
\text { expected that: } \\
\text { it can decrease the operation costs } \\
\text { it can increase efficiency } \\
\text { it can simplify the operation processes } \\
\text { it can bring along a high-tech image } \\
\text { a large number of our competitors and business partners have already adopted e- } \\
\text { business practices } \\
\text { it can enhance company status and reputation }\end{array}$ \\
\hline $\begin{array}{l}\text { IT usage for } \\
\text { Pre-Show } \\
\text { promotion } \\
\text { Adopted } \\
\text { Prasad et al. } \\
\text { (2001) }\end{array}$ & $\begin{array}{l}\text { My company's website enables } \\
\text { to locate and send information concerning participation in a particular trade show to } \\
\text { the appropriate contact persons in the company } \\
\text { usage of company X's website for displaying general information about the company } \\
\text { and participation in a particular show } \\
\text { sending personalised e-mail and invitation letters to clients and partners to increase } \\
\text { the booth attendance } \\
\text { usage of company X's website and personalised e-mails for providing customers with } \\
\text { regular updates about new products/services and other developments within the } \\
\text { company }\end{array}$ \\
\hline $\begin{array}{l}\text { IT usage for } \\
\text { At-show } \\
\text { promotion } \\
\text { Adopted } \\
\text { from Prasad } \\
\text { et al. (2001) }\end{array}$ & $\begin{array}{l}\text { My company's website enables } \\
\text { the usage of company website for product/services demonstration to potential clients } \\
\text { the usage of company website for provision of quotation } \\
\text { the usage of company website for providing solutions to potential customer problems } \\
\text { at trade show }\end{array}$ \\
\hline $\begin{array}{l}\text { IT usage for } \\
\text { After-show } \\
\text { follow-up } \\
\text { Adopted } \\
\text { from Prasad } \\
\text { et al. }(2001)\end{array}$ & $\begin{array}{l}\text { My company's website enables } \\
\text { the usage of website for providing solutions to potential customer problems at } \\
\text { particular trade show } \\
\text { the usage of website for providing after-sales service to customer } \\
\text { the usage of personalised e-mails for after-show follow-up } \\
\text { the usage of website/ personalised e-mails for providing information in respond to } \\
\text { customer requests and questions }\end{array}$ \\
\hline $\begin{array}{l}\text { Achievement } \\
\text { of trade } \\
\text { show } \\
\text { objectives }\end{array}$ & $\begin{array}{l}\text { My company's website enables } \\
\text { achievement of maintaining existing customer contacts } \\
\text { achievement of getting new customer contacts } \\
\text { achievement of promoting existing products } \\
\text { achievement of increasing sales orders }\end{array}$ \\
\hline
\end{tabular}




\section{Author Biographies}

Jaywant Singh is Associate Professor in Marketing at Kingston Business School, Kingston University London. His research interests are primarily in the areas of consumer behaviour, branding, and services marketing. His research has been published, amongst others, in the Journal of Business Research, Marketing Letters, Journal of Advertising Research, Industrial Marketing Management, European Journal of Marketing, Journal of Business \& Industrial Marketing, and Journal of Business Ethics.

Paurav Shukla is Professor of Luxury Brand Marketing at Glasgow Caledonian University London. His research interests include cross-cultural consumer behaviour, luxury marketing and branding, and marketing in emerging markets. He has published on these topics in a wide range of outlets, including the Journal of Business Research, International Marketing Review, Journal of World Business, Information \& Management, Psychology \& Marketing, Journal of Consumer Behaviour, Journal of Business \& Industrial Marketing, amongst others.

Stavros P. Kalafatis is Professor of Business Marketing at Kingston Business School, Kingston University London. His research focuses on business segmentation, design of channels of distribution, relationship marketing and value creation. His research has been published, amongst others, in European Journal of Marketing, Industrial Marketing Management, Journal of Business Research, and Journal of Marketing Management. 